\title{
Working Capital Management Efficiency of Cement Sector of Pakistan
}

\author{
Talat Afza and Mian Sajid Nazir* \\ Department of Management Sciences, COMSATS Institute of Information Technology, Lahore, Pakistan \\ *sajidnazir2001@yahoo.com
}

\begin{abstract}
The corporate finance literature has traditionally focused on the study of long-term financial decisions. Researchers have particularly examined investments, capital structure, dividends or company valuation decisions, among other topics. However, short-term assets and liabilities are important components of total assets and needs to be carefully analyzed. Management of these short-term assets and liabilities warrants a careful investigation since the working capital management plays an important role for the firm's profitability and risk as well as its value. It requires continuous management to maintain proper level in various components of working capital i.e. cash, receivables, inventory and payables etc. The present study is an attempt to evaluate the efficiency of the working capital management of cement sector of Pakistan for the period 1988-2008. Instead of employing the traditional ratios; working capital efficiency has been measured in terms of utilization index, performance index and total efficiency index as suggested by Bhattacharya (1997). This paper also tests the speed of achieving the target level of efficiency by an individual firm during the period of study using industry norms as the target level of efficiency. Findings of the study indicate that the cement sector as a whole did perform well during the study period.
\end{abstract}

Keywords: Working capital, efficiency, utilization index, performance index, cement sector, Pakistan

\section{Introduction}

The corporate finance literature has traditionally focused on the study of long-term financial decisions, particularly investments, capital structure, dividends or company valuation decisions. However, shortterm assets and liabilities are important components of total assets and needs to be carefully analyzed. Management of these short-term assets and liabilities warrants a careful investigation since the working capital management plays an important role for firm's profitability and risk as well as its value (Smith, 1980). Efficient management of working capital is an important component of overall corporate strategy to create the shareholders' value. Firms try to keep an optimal level of working capital that maximizes their value (Howorth and Westhead, 2003, Deloof, 2003, Afza and Nazir, 2007a, b; Afza and Nazir, 2008, and Nazir and Afza, 2009a, b).

In a broader spectrum, from the perspective of Chief Financial Officer (CFO), working capital management is a simple and straightforward concept of ensuring the ability of an organization to fund/invest the difference between the short term assets and short term liabilities (Harris, 2005). However, a "Total" approach should be followed which covers all the company's activities relating to vendor, customer and product (Hall, 2002). In practice, working capital management has become one of the most important issues in the organizations where many financial executives are struggling to identify the basic working capital drivers and the appropriate level of working capital (Lamberson, 1995). Consequently, companies can minimize risk and improve the overall performance by understanding the role and drivers of working capital. A firm may adopt an aggressive working capital management policy with a low level of current assets as percentage of total assets or it may also be used for the financing decisions of the firm in the form of high level of current liabilities as percentage of total liabilities. Excessive levels of current assets may have a negative effect on the firm's profitability whereas a low level of current assets may lead to lower level of liquidity and stock-outs resulting in difficulties in maintaining smooth operations (Bhattacharya, 1997; and Van Horne and Wachowicz, 2004).

The main objective of working capital management is to maintain an optimal balance between each of the working capital components. Business success heavily depends on the ability of financial executives to effectively manage receivables, inventory, and payables (Filbeck and Krueger 2005; Parsad, 2001). Firms can reduce their financing costs and/or increase the funds available for expansion projects by minimizing the amount of investment tied up in current assets. Most of the financial managers' time and effort are allocated in bringing sub-optimal levels of current assets and liabilities back toward optimal levels 
(Lamberson, 1995). An optimal level of working capital would be the one in which a balance is achieved between risk and efficiency (Yadav, 1986). It requires continuous monitoring working capital to maintain proper level of its various components i.e. cash receivables, inventory and payables etc. However, it is a difficult task to estimate the working capital actually required because it varies across companies over time depending upon operational scale, nature of business, credit policy, production cycle, inventory availability and other distinctive factors.

In general, current assets are considered as one of the important component of total assets of a firm. A firm may be able to reduce the investment in fixed assets by renting or leasing plant and machinery, whereas, the same policy cannot be followed for the components of working capital. The high level of current assets may reduce the risk of liquidity associated with the opportunity cost of funds that may have been invested in long-term assets. Thus, efficient management of working capital is an important indicator of sound health of an organization which requires reduction of unnecessary blocking of capital in order to bring down the cost of financing. In the light of the above, an attempt is made in this study to look into the efficiency of working capital management of cement industry of Pakistan.

Cement industry is indeed a highly important segment of industrial sector that plays a pivotal role in the socio-economic development and growth of cement industry is rightly considered a barometer for economic activity. In 1947, Pakistan had inherited 4 cement plants with a total capacity of 0.5 million tons. However, by the end of June 2011, the installed cement production capacity will touch to the level of 49.579 million tones with 29 operating units of cement (Baig, 2008). For the period from 2003 to 2008 cement industry of Pakistan had registered an average growth rate of $20 \%$ due to economic boom in the country and high economic growth rate. Although an oligopoly market, there exists fierce competition between members of the cartel today. The industry comprises of 29 units 19 units in the north and 10 units in the south), with the installed production capacity of 44.09 million tons. There are 4 foreign companies, 3 armed forces companies and 15 private companies listed in the Karachi Stock Exchange. The capacity utilization of cement sector has been, on average, above $80 \%$ in last decade; hence making analysis of its working capital management efficiency worth investigating.

The specific objectives of the study are: (a) to examine the efficiency of working capital management practices of the selected firms in cement industry. (b) To test how fast the sample firms have been able to improve their respective level of efficiency in working capital management with respect to a target level (industry average). It is expected that the present study may contribute to better understand the levels of working capital efficiency of cement sector of emerging markets like Pakistan. The remainder of the paper is organized as follows: Section II briefly reviews some relevant literature on the effective and efficient management of working capital. Section III covers the population, dataset and methodology adopted; followed by the empirical analyses presented in section IV. Conclusions and discussion are reported in the last section of the study.

\section{Literature Review}

Many researchers have focused on financial ratios as a part of working capital management; however, very few of them have discussed the working capital policies in specific. Some earlier work by Gupta (1969) and Gupta and Huefner (1972) examined the differences in financial ratio averages between the industries. The conclusion of both the studies was that differences do exist in mean profitability, activity, leverage and liquidity ratios amongst industry groups. Johnson (1970) extended this work by finding cross-sectional stability of ratio groupings for both retailers and primary manufacturers. Pinches et al. (1973) used factor analysis to develop seven classifications of ratios, and found that the classifications were stable over the 1951-1969 time period. Filbeck and Krueger (2005) highlighted the importance of efficient working capital management by analyzing the working capital management policies of 32 nonfinancial industries of USA. According to their findings significant differences exist between industries in working capital practices over time. Moreover, these working capital practices, themselves, change significantly within industries over time. Similar studies are conducted by Gombola and Ketz (1983), Soenen (1993), Maxwell et al. (1998), and Long et al. (1993). Weinraub and Visscher (1998) have discussed the issue of aggressive and conservative working capital management policies of US firms. The authors have concluded that the industries had distinctive, stable and significantly different working capital management policies. Moreover, the study also showed a high and significant negative correlation between industry asset and liability policies and found that when relatively aggressive working capital asset policies are followed they are balanced by relatively conservative working capital financial policies. 
In literature, there is a long debate on the risk/return tradeoff between different working capital policies (Pinches, 1991, Brigham and Ehrhardt, 2004, Moyer et. al. 2005, Gitman, 2005). More aggressive working capital policies are associated with higher return and higher risk while conservative working capital policies are concerned with the lower risk and return (Gardner et al. 1986, Weinraub and Visscher, 1998). Working capital management is important because of its effects on the firm's profitability and risk, and consequently its value (Smith, 1980). The Greater the investment in current assets, the lower the risk, but also the lower the profitability. In contrast, Carpenter \& Johnson (1983) provided empirical evidence that there is no linear relationship between the level of current assets and revenue systematic risk of US firms; however, some indications of a possible non-linear relationship were found though not highly statistically significant.

For the first time, Soenen (1993) investigated the relationship between the net trade cycle as a measure of working capital and return on investment and found a negative relationship between the length of net trade cycle and return on assets. In order to validate the results of Soenen (1993) on large sample and with longer time period, Jose et al. (1996) examined the relationship between aggressive working capital management and profitability of US firms using Cash Conversion Cycle (CCC) as a measure of working capital management. The results indicated a significant negative relationship between the cash conversion cycle and profitability indicating that more aggressive working capital management is associated with higher profitability. Shin and Soenen (1998) concluded that reducing the level of current assets to a reasonable extent increases firms' profitability. Later on, Deloof (2003) analyzed a sample of large Belgian firms during the period 1992-1996 and the results confirmed that Belgian firms can improve their profitability by reducing the number of days accounts receivable are outstanding and reducing inventories. Teruel and Solano (2005) suggested that managers can create value by reducing their firm's number of days accounts receivable and inventories. Similarly, shortening the cash conversion cycle also improves the firm's profitability. Finally, in the Pakistani context, Nazir and Afza (2009) used panel data to investigate the relationship of working capital management and firm's profitability for the period of 1998-2005. They have extended the work of Rehman (2006) who looked into working average collection period, inventory turnover period; average payment period and cash conversion cycle as working capital management for 94 firms listed at Islamabad Stock Exchange. The authors reported that managers can create value if they adopt a conservative approach towards working capital investment and working capital financing policies in Pakistan. However, if firms adopt aggressive approach to manage the short term liabilities, investors give more value to those firms in stock markets. Similar studies on working capital and profitability includes Smith and Begemann (1997), Howorth \& Westhead (2003), Eljelly (2004), Lazaridis and Tryfonidis (2006), Rehman and Nasr (2007), Afza and Nazir $(2007,2008)$ and Rehman et al. (2010).

Though accounting ratios played a very important role in most of earlier empirical investigations, but a choice of ratios or group of ratios is often a difficult task due to the absence of a proper theory of ratio analysis (Bhattacharya, 1997). To overcome this problem Bhattacharya (1997) developed an alternative ratio model for the measurement and monitoring the efficiency of working Capital Management. He decomposed the total efficiency index of the working capital management into performance index and utilization index. Ghosh and Maji (2004) used these models to investigate the efficiency of working capital management of Indian firms and found that these firms did not perform remarkably well with respect of working capital management and there is further need to investigate the application of efficiency index to firms in other sectors as well. The present study also uses the efficiency index developed by Bhattacharya (1997) in order to measure the working capital performance and utilization as well as total efficiency for the cement sector of Pakistan for a period of 21 years i.e. 1988-2008.

\section{Research Design and Methodology}

This study is based on data of cement companies operating in Pakistan from a period of 1988-2008. Currently, there are 22 cement companies operating in Pakistan and data for these companies was collected from the various editions of "Balance Sheet Analysis of Joint Stock Companies listed on the Karachi Stock Exchange" published by State Bank of Pakistan (SBP). Following Bhattacharya (1997), for measuring the efficiency of working capital management (WCM), first the Utilization Index of Working Capital Management (UI $\left.\mathrm{WCM}_{\mathrm{W}}\right)$, was calculated by applying the following model:

$\mathrm{UI}_{\text {WCM (it) }}=\frac{\mathrm{A}_{\mathrm{t}-1}}{\mathrm{~A}_{\mathrm{t}}}$

Where, $A$ = current assets/sales. 
Next is the measure the working capital efficiency based on Performance Index of Working Capital Management' ( $\mathrm{PI}_{\mathrm{WCM}}$ ), which was calculated as:

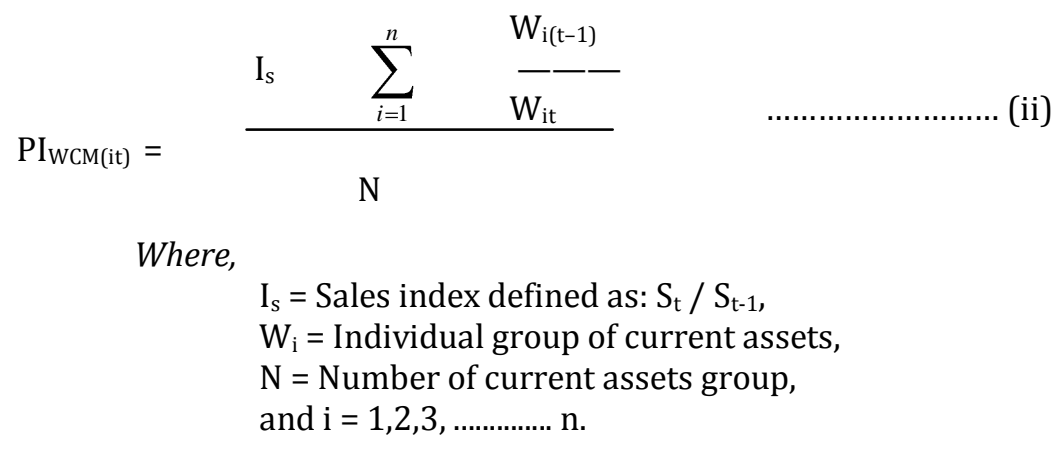

Total current assets were divided into five components: cash, short term marketable securities, inventory, accounts receivables, and other current assets. Finally, the Efficiency Index of Working Capital Management (EI $\mathrm{wcm}_{\mathrm{wc}}$ ) was calculated by multiplying the overall performance index of working capital management with the working capital utilization index. Thus,

$\mathrm{EI}_{\mathrm{WCM}(\mathrm{it})}=\mathrm{UI}_{\mathrm{WCM}} \times \mathrm{PI}_{\mathrm{WCM}}$

Furthermore, in order to measure the firm's efficiency in achieving the target level of efficiency during the study period following regression model had been used as:

$$
\begin{aligned}
& \mathrm{Y}_{\mathrm{it}}=\alpha+\beta \mathrm{Xit}+\varepsilon \\
& \text { Where, } \\
& \mathrm{Y}_{\mathrm{it}}=\mathrm{Z}_{\mathrm{it}}-\mathrm{Z}_{\mathrm{it}-1} \text {, } \\
& X_{\mathrm{it}}=Z^{*}{ }_{\mathrm{t}}-\mathrm{Z}_{\mathrm{it}-1} \text {, } \\
& Z_{\mathrm{it}}=\text { Index at time } \mathrm{t} \text { for the firm } i \text { and } \\
& Z^{*}=\text { Average index of the industry at } t_{-1} \text {. }
\end{aligned}
$$

The coefficient of the regression equation (iv) i.e. $(\beta)$ represents the speed of the individual firm in improving its efficiency vis-à-vis the industry norms. In this regard, $(\beta)=1$ for a firm indicates that the degree of firms efficiency in managing working capital is equal to the average efficiency level of the industry as a whole. Similarly, $(\beta)<1$, indicates the need of further improvements by the firms in working capital management. In order to ensure for control on outliers, median value was been taken as the target industry norms for the present purpose. Equally-weighted mean or value-weighted mean could also be used in place of median. However, these were not been considered in the present study.

\section{Empirical Analysis}

Table 1,2, and 3 report the descriptive statistics of cement sector firms for Utilization Index, Performance index, and Efficiency Index of working capital management. With respect to Utilization Index of working capital management, which indicate the ability of the firm to generate sales by efficiently utilizes the current assets as a whole. If an increase in total current assets is coupled with more than proportionate rise in sales, the degree of utilization of these assets with respect to sales is said to have improved and vice versa which ultimately reflects the operating cycle of the firm which can be shortened by means of increasing the degree of utilization. Thus, a value of Utilization Index of working capital management grater than one is desired by the firms. A quick look into the Table 1 discloses the fact that cement sector as a whole did not perform well based upon Utilization Index of working capital management. Almost 11 of the 20 years, the average index value for utilization of working capital management is less than 1 . The year 1995 proved to be the worst year for UI wcm $_{\text {as }}$ it scored 0.84 index value (lowest) whereas the very next year of 1996 was the most successful where index value of UI ${ }_{\text {wcm }}$ was 1.78 due to increased level of current assets in the later year. Moreover, it is also noticeable from the table, as a whole, the efficiency of current assets utilization remained instable during the study period.

Table 2 presents individual firms' statistics for the cement industry. The index values for $\mathrm{UI}_{\mathrm{Wcm}}$ varied between 0.09 (Pakistan Slag Cement in 1998) and 6.67 (Pakistan Slag Cement in 1996). The range for the 


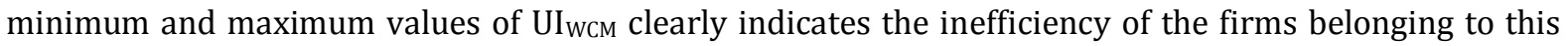
industry in the matter of utilization of current assets. This range is minimum in the case of Lafarge Pakistan Cement where minimum and maximum values are equal. However, this firm is an exception as only one year data was available to be analyzed for the firm (that's why this firm was excluded from the sample while estimating the equation (iv)). Besides this, Bestway Cement, a multinational cement firm, has the minimum range value for UI ${ }_{\text {wCM }}(0.69)$. On average, approximately all the cement firms are earning index value greater than one except Bestway Cement, DG Khan Cement and Zeal Pak Cement, for which $\mathrm{UI}_{\mathrm{Wcm}}$ are very close to $1(0.97,0.99$, and 0.97 respectively). On the individual basis, the cements firms have reached the desired level of working capital utilization and those who did not, are approaching to it.

Table 1: Industry Averages (1989-2008)

\begin{tabular}{llllllllll}
\hline \multirow{2}{*}{ Year } & \multicolumn{3}{c}{ Utilization Index } & \multicolumn{3}{c}{ Performance Index } & \multicolumn{3}{c}{ Efficiency Index } \\
\cline { 2 - 10 } & Min. & Max. & Avg. & Min. & Max. & Avg. & Min. & Max. & Avg. \\
\hline 1989 & 0.70 & 1.26 & 1.04 & 0.74 & 2.16 & 1.38 & 0.52 & 2.24 & 1.44 \\
1990 & 0.67 & 1.11 & 0.85 & 0.63 & 1.24 & 0.85 & 0.42 & 1.38 & 0.75 \\
1991 & 0.45 & 1.46 & 1.10 & 0.87 & 1.54 & 1.19 & 0.52 & 2.09 & 1.32 \\
1992 & 0.64 & 1.36 & 1.10 & 0.77 & 2.56 & 1.33 & 0.49 & 3.45 & 1.54 \\
1993 & 0.31 & 2.09 & 0.93 & 0.46 & 3.24 & 2.07 & 0.14 & 4.38 & 1.19 \\
1994 & 0.56 & 1.35 & 0.97 & 0.52 & 5.08 & 2.42 & 0.29 & 1.73 & 2.42 \\
1995 & 0.21 & 1.99 & 0.84 & 0.36 & 1.86 & 0.99 & 0.08 & 3.43 & 0.98 \\
1996 & 0.57 & 5.67 & 1.78 & 0.68 & 7.42 & 2.67 & 0.50 & 8.86 & 5.66 \\
1997 & 0.74 & 2.14 & 1.30 & 0.88 & 6.18 & 3.20 & 0.74 & 7.03 & 2.67 \\
1998 & 0.09 & 2.86 & 0.93 & 0.09 & 4.42 & 6.63 & 0.01 & 4.30 & 1.65 \\
1999 & 0.62 & 5.04 & 1.60 & 0.75 & 6.33 & 4.35 & 0.63 & 6.94 & 6.26 \\
2000 & 0.13 & 2.02 & 1.00 & 0.06 & 5.07 & 1.28 & 0.01 & 6.22 & 1.54 \\
2001 & 0.71 & 7.80 & 1.47 & 0.57 & 5.48 & 1.83 & 0.46 & 2.76 & 3.91 \\
2002 & 0.57 & 1.37 & 0.98 & 0.63 & 4.10 & 1.60 & 0.36 & 5.54 & 1.53 \\
2003 & 0.50 & 1.80 & 1.03 & 0.65 & 3.08 & 1.41 & 0.32 & 4.94 & 1.65 \\
2004 & 0.32 & 1.55 & 0.95 & 0.39 & 3.81 & 1.42 & 0.13 & 3.08 & 1.40 \\
2005 & 0.51 & 1.83 & 1.03 & 0.51 & 3.09 & 1.27 & 0.33 & 5.66 & 1.51 \\
2006 & 0.25 & 1.81 & 0.93 & 0.54 & 6.93 & 1.72 & 0.22 & 5.86 & 1.62 \\
2007 & 0.23 & 1.46 & 0.87 & 0.16 & 5.54 & 4.02 & 0.20 & 4.24 & 3.95 \\
2008 & 0.37 & 2.65 & 1.16 & 0.54 & 6.54 & 1.94 & 0.24 & 7.70 & 2.28 \\
\hline
\end{tabular}

While the UI ${ }_{\text {Wcm }}$ characterizes firms in utilizing current assets as a whole to generate the desired level of sales, $\mathrm{PI}_{\mathrm{WCM}}$ represents the firms' ability in managing the different components of current assets with respect to their performance. A firm may be said to have managed its working capital efficiently if the proportionate rise in sales is more than the proportionate rise in current assets during a particular period. Numerically, overall performance index value of more than 1 indicates efficient management of working capital. The performance index of the industry as a whole (Table 1) shows that average performance index was more than one in 18 out 20 years. The lowest value of PI wcm was in $2000(0.06)$ whereas the maximum index value was in year 1996 (7.33). Thus, the performance of the industry as whole was mostly efficient during the period of study.

In Table 2, firm specific analysis reveals that the performance index varied from 0.06 (Dandot Cement in 2000) to 7.42 (Deewan Hattar Cement in 1998). On average, all the firms have achieved the desired index

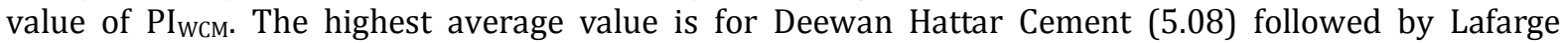
Pakistan Cement (4.44). The least efficient firm with regards to PI wcm $_{\text {has }}$ been Zeal Pak Cement which

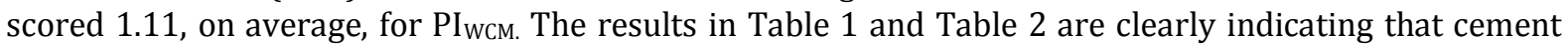
sector firms are best managing their current assets in order to generate the desired levels of sales. The proportionate rise in the level of sales has remained at a higher level as compared to proportionate increase in the level of individual levels of current assets. So the cement sector firms may be considered as 'Efficient' individually as well as industry as a whole with respect to $\mathrm{PI}_{\mathrm{Wcm}}$. 
Table 2: WCM Index Value of Cement Sector Companies: 1989-2008

\begin{tabular}{|c|c|c|c|c|c|c|c|c|c|c|}
\hline \multirow{2}{*}{$\mathbf{S} / \mathbf{N}$} & \multirow{2}{*}{ Name of Company } & \multicolumn{3}{|c|}{ Utilization Index } & \multicolumn{3}{|c|}{ Performance Index } & \multicolumn{3}{|c|}{ Efficiency Index } \\
\hline & & Avg. & Max. & Min & Avg. & Max. & Min & Avg. & Max. & Min \\
\hline 1 & Al-Abbas Cement Ltd. & 1.04 & 2.65 & 0.24 & 1.70 & 5.07 & 0.39 & 1.98 & 5.22 & 0.27 \\
\hline 2 & Attock Cement Ltd. & 1.13 & 1.81 & 0.63 & 1.26 & 1.67 & 0.75 & 1.52 & 2.62 & 0.47 \\
\hline 3 & Bestway Cement Ltd. & 0.97 & 1.16 & 0.69 & 1.21 & 1.87 & 0.84 & 0.99 & 1.46 & 0.67 \\
\hline 4 & Cherate Cement Ltd. & 1.01 & 1.73 & 0.67 & 1.31 & 3.08 & 0.58 & 1.36 & 2.60 & 0.43 \\
\hline 5 & Dadabhoy Cement Ltd. & 1.10 & 2.35 & 0.35 & 2.30 & 6.54 & 0.49 & 2.47 & 7.04 & 0.28 \\
\hline 6 & Dadex Eternit Ltd. & 1.05 & 1.53 & 0.74 & 2.49 & 15.08 & 0.68 & 2.47 & 11.73 & 0.65 \\
\hline 7 & Dandot Cement Ltd. & 1.33 & 4.80 & 0.13 & 3.89 & 6.33 & 0.06 & 8.63 & 6.94 & 0.01 \\
\hline 8 & Deewan Cement Ltd. & 1.08 & 1.77 & 0.31 & 2.99 & 5.54 & 0.52 & 3.63 & 9.24 & 0.17 \\
\hline 9 & $\begin{array}{l}\text { Deewan Hattar Cement } \\
\text { Ltd. }\end{array}$ & 1.32 & 1.44 & 1.19 & 5.08 & 7.42 & 0.64 & 1.77 & 3.24 & 0.80 \\
\hline 10 & DG Khan Cement Ltd. & 0.99 & 1.93 & 0.46 & 1.32 & 4.87 & 0.55 & 1.45 & 7.03 & 0.25 \\
\hline 11 & Fauji Cement Ltd. & 1.02 & 2.66 & 0.37 & 1.46 & 2.71 & 0.66 & 1.60 & 6.94 & 0.24 \\
\hline 12 & Fecto Cement Ltd. & 1.08 & 2.45 & 0.60 & 1.42 & 2.80 & 0.54 & 1.75 & 6.84 & 0.32 \\
\hline 13 & Gharibwal Cement Ltd. & 1.05 & 2.24 & 0.23 & 1.97 & 6.02 & 0.46 & 1.62 & 3.96 & 0.14 \\
\hline 14 & Javedan Cement Ltd. & 1.04 & 1.79 & 0.64 & 1.70 & 6.76 & 0.68 & 1.93 & 2.59 & 0.48 \\
\hline 15 & Kohat Cement Ltd. & 1.26 & 5.64 & 0.21 & 1.35 & 4.18 & 0.36 & 2.75 & 3.58 & 0.08 \\
\hline 16 & $\begin{array}{l}\text { Lafarge Pakistan Cement } \\
\text { Ltd }\end{array}$ & 1.20 & 1.20 & 1.20 & 4.44 & 6.18 & 0.16 & 7.70 & 7.70 & 7.70 \\
\hline 17 & Lucky Cement Ltd. & 1.20 & 2.86 & 0.32 & 2.04 & 7.33 & 0.39 & 2.90 & 4.30 & 0.13 \\
\hline 18 & Mapple Leaf Cement Ltd. & 1.11 & 2.36 & 0.33 & 1.88 & 6.94 & 0.44 & 2.68 & 6.41 & 0.17 \\
\hline 19 & Mustehkam Cement Ltd. & 1.01 & 1.55 & 0.25 & 1.62 & 4.10 & 0.62 & 1.71 & 5.54 & 0.41 \\
\hline 20 & Pakistan Slag Cement Ltd. & 1.52 & 6.67 & 0.09 & 1.56 & 4.33 & 0.09 & 4.52 & 8.86 & 0.01 \\
\hline 21 & Pioneer Cement Ltd. & 1.12 & 1.74 & 0.53 & 2.37 & 3.24 & 0.62 & 2.25 & 1.34 & 0.45 \\
\hline 22 & Zeal Pak Cement Ltd. & 0.97 & 2.28 & 0.48 & 1.11 & 1.85 & 0.53 & 1.19 & 3.98 & 0.25 \\
\hline
\end{tabular}

Moreover, Table 1 and 2 also report overall Efficiency Index values for the cement firms and cement industry. Efficiency index is the product of the performance index and the utilization index and measures the ultimate efficiency in working capital management of a firm. It is evident from Table 1 that EI wCM was minimum in 1998 and 2000 (Index value 0.01) for the cement sector with maximum value in 1996 (8.86). The cement industry's average efficiency of working capital was at its peak in year 1999 with the minimum value in year 1990. It can be observed from the table that overall efficiency of cement sector with respect to working capital management has remained satisfactory as index value of EI $\mathrm{I}_{\mathrm{WCM}}$ was greater than 1 in 18 out of 20 years of the study. When it comes to firm specific analysis, with the exception of Bestway cement ( I $_{\mathrm{WCM}}$ 0.99), the whole cement sector was efficient during the study period.

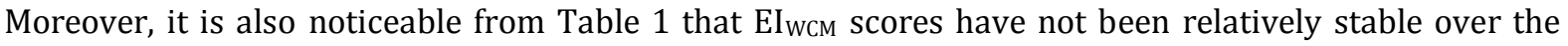
years although these values were greater than the desired level of efficiency score of 1 . Table 3 also represents the number of the efficient firms on three of the index values over the window period. The year 1997, on average, was the most successful year for the cement industry where number of efficient firms on all three indices of WCM has been highest (12 (75\%), 16 (100\%), and 12 (75\%) respectively for $\mathrm{UI}_{\mathrm{WCM}}, \mathrm{PI}_{\mathrm{WCM}}$, and $\left.\mathrm{EI}_{\mathrm{WCM}}\right)$. 
Table 3: No. of Efficient Firms (Index Value $\geq 1$ )

\begin{tabular}{cccccccc}
\hline & Total & \multicolumn{2}{c}{ Utilization Index } & Performance Index & \multicolumn{2}{c}{ Efficiency Index } \\
\cline { 3 - 7 } & Firms & $\begin{array}{c}\text { Efficient } \\
\text { Firms }\end{array}$ & \%age & $\begin{array}{c}\text { Efficient } \\
\text { Firms }\end{array}$ & \%age & $\begin{array}{c}\text { Efficient } \\
\text { Firms }\end{array}$ & \%age \\
\hline 1989 & 6 & 4 & 66.67 & 5 & 83.33 & 5 & 83.33 \\
1990 & 8 & 1 & 12.50 & 1 & 12.50 & 5 & 62.50 \\
1991 & 9 & 8 & 88.89 & 7 & 77.78 & 7 & 77.78 \\
1992 & 9 & 7 & 77.78 & 5 & 55.56 & 6 & 66.67 \\
1993 & 11 & 4 & 36.36 & 9 & 81.82 & 4 & 36.36 \\
1994 & 12 & 5 & 41.67 & 8 & 66.67 & 5 & 41.67 \\
1995 & 15 & 5 & 33.33 & 7 & 46.67 & 4 & 26.67 \\
1996 & 16 & 10 & 62.50 & 14 & 87.50 & 11 & 68.75 \\
1997 & 16 & 12 & 75.00 & 16 & 100.00 & 12 & 75.00 \\
1998 & 17 & 5 & 29.41 & 11 & 64.71 & 7 & 41.18 \\
1999 & 18 & 13 & 72.22 & 17 & 94.44 & 14 & 77.78 \\
2000 & 18 & 7 & 38.89 & 10 & 55.56 & 9 & 50.00 \\
2001 & 18 & 10 & 55.56 & 14 & 77.78 & 11 & 61.11 \\
2002 & 18 & 8 & 44.44 & 15 & 83.33 & 12 & 66.67 \\
2003 & 18 & 8 & 44.44 & 12 & 66.67 & 9 & 50.00 \\
2004 & 18 & 7 & 38.89 & 16 & 88.89 & 11 & 61.11 \\
2005 & 21 & 9 & 42.86 & 12 & 57.14 & 10 & 47.62 \\
2006 & 21 & 10 & 47.62 & 13 & 61.90 & 12 & 57.14 \\
2007 & 21 & 11 & 52.38 & 13 & 61.90 & 13 & 61.90 \\
2008 & 22 & 11 & 50.00 & 15 & 68.18 & 13 & 59.09 \\
\hline
\end{tabular}

Finally, in order to measure the efficiency and speed of cement sector firms to achieve the target level of working capital efficiency, equation (iv) of regression model has been estimated as discussed in methodology section. While analyzing the financial health of firms, average performance of an industry is considered as the benchmark for performance evaluation of the firms belonging to that industrial sector. For calculating industry norms, any measure of central tendency, (either mean or median) can be used. In the present study, industry norms have been estimated for each of the three working capital management indexes by using the median values. One main benefit of using median as the industry norm is that the existence of any extreme value cannot affect the industry average. The results of the regression model for the three indexes of working capital management $\mathrm{UI}_{\mathrm{WCM}}, \mathrm{PI}_{\mathrm{WCM}}$ and $\mathrm{EI}_{\mathrm{WCM}}$ have been reported in Table 46 , respectively.

Table 4 reports the results of $\mathrm{UI}_{\mathrm{Wcm}}$ for each of the cement sector firms in our or study. Due to less number of observations, Lafarge Pakistan Cements Ltd. has been dropped from the sample leaving us with a total of 21 firms in the cement sector of Pakistan. The table describes the values of constant, $\beta, F-$ value, $\mathrm{R}^{2}$, and Durbin-Watson value of the models estimated for each of the individual firms in the sample. In total, there are 21 regressions estimated for each of the three working capital management indexes used in the present study. It is evident from the estimated $\beta$ values that efficiency of cement firms to achieve the industry' target level of working capital efficiency ranges from 51\% (Deewan Cement) to 99.4\% (Deewan Hattar Cement). Although the company has utilized its current assets well in order to generate sales, however, this efficiency level could not be maintained in performance and efficiency index of working capital management where Bestway Cement and Al-Abbas Cement have outperformed the rest of firms in cement sector. However, it is worth mentioning based on the estimated results that none of the firms has obtained the $\beta$ value greater than one (i.e. outperform the industry as a whole). So, a room for improvement is still there for the cement firms of Pakistan.

The ranking of the firms with respect of $\beta$ values working capital management indexes has been reported

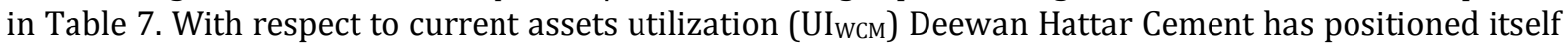
as top firm followed by Attock Cement and Bestway Cement. Whereas Deewan Cement has been sluggish in achieving targeted level of current assets utilization in cement sector followed by Zeal Pak Cement and DG Khan Cement. On the basis of performance of current assets, the most successful firm is Bestway

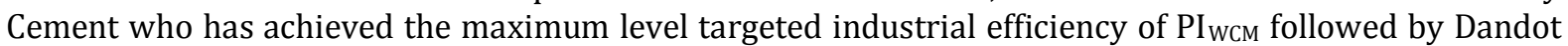
and Mapple Leaf Cement. Contrary to this, Deewan Hattar Cement, Fauji Cement and Lucky Cement have 
been worst firms in aligning their working capital performance with the industry. Al-Abbas cement has been most thriving firms with respect to overall efficiency of working capital management (EI WcM ) beating rest of the firms in cement industry. It is worth noticeable in Table 7 results that firms have been volatile while maintaining their ranking with respect of three indexes of working capital management. In this regards, the least variation is observable in Dandot Cement which is on $7^{\text {th }}, 2^{\text {nd }}$, and $2^{\text {nd }}$ rank in UIwcm, $\mathrm{PI}_{\mathrm{WCM}}$, and $\mathrm{EI}_{\mathrm{WCM}}$, respectively. While, Deewan Hattar Cement was, correspondingly, most successful as well as worse firm while achieving the targeted industrial level of working capital management efficiency on $\mathrm{UI}_{\mathrm{WCM}}, \mathrm{PI}_{\mathrm{WCM}}$, and $\mathrm{EI}_{\mathrm{WCM}}$. Thus, on the whole, scope for the improvement in the matter of managing either the individual components of current assets or the current assets as a whole for generating increased sales revenue is found for cement sector firms. A careful attention to this would help the firms in enhancing their efficiency in working capital management. In the context of the present highly distressed market situation, these scopes should be properly addressed.

Table 4: Regression Results -- Utilization Index

\begin{tabular}{|c|c|c|c|c|c|c|}
\hline S. No. & Name of Company & Constant & $\boldsymbol{\beta}$ & F-Value & $\mathbf{R}^{2}$ & D-W \\
\hline 1 & Al-Abbas Cement Ltd. & -0.069 & $\begin{array}{l}.625^{* * *} \\
(3.206)\end{array}$ & $10.281^{* * *}$ & 0.391 & 1.73 \\
\hline 2 & Attock Cement Ltd. & 0.177 & $\begin{array}{l}.906^{*} \\
(3.024)\end{array}$ & $9.146^{* * *}$ & 0.821 & 2.85 \\
\hline 3 & Bestway Cement Ltd. & 0.073 & $\begin{array}{l}.847^{* *} \\
(2.257)\end{array}$ & $5.09^{* *}$ & 0.718 & 2.34 \\
\hline 4 & Cherate Cement Ltd. & -0.039 & $\begin{array}{l}.630 * * * \\
(3.345)\end{array}$ & $11.187^{* * *}$ & 0.397 & 2.05 \\
\hline 5 & Dadabhoy Cement Ltd. & -0.05 & $\begin{array}{l}.824^{* * *} \\
(5.450)\end{array}$ & $29.706^{* * *}$ & 0.680 & 2.90 \\
\hline 6 & Dadex Eternit Ltd. & -0.023 & $\begin{array}{l}.530^{* *} \\
(2.577)\end{array}$ & $6.639 * *$ & 0.281 & 3.31 \\
\hline 7 & Dandot Cement Ltd. & 0.282 & $\begin{array}{l}.749^{* * *} \\
(4.654)\end{array}$ & $21.662^{* * *}$ & 0.560 & 2.21 \\
\hline 8 & Deewan Cement Ltd. & -0.039 & $\begin{array}{l}.508^{* *} \\
(2.433)\end{array}$ & $5.920^{* *}$ & 0.258 & 1.96 \\
\hline 9 & $\begin{array}{l}\text { Deewan Hattar Cement } \\
\text { Ltd. }\end{array}$ & $.366^{* *}$ & $\begin{array}{l}.994^{* * *} \\
(12.932)\end{array}$ & $167.23^{* * *}$ & 0.988 & 2.80 \\
\hline 10 & DG Khan Cement Ltd. & -0.082 & $\begin{array}{l}.528^{* *} \\
(2.327)\end{array}$ & $5.414^{* *}$ & 0.279 & 2.21 \\
\hline 11 & Fauji Cement Ltd. & -0.123 & $\begin{array}{l}.845^{* * *} \\
(4.472)\end{array}$ & $20.000^{* * *}$ & 0.714 & 1.02 \\
\hline 12 & Fecto Cement Ltd. & -0.028 & $\begin{array}{c}.584^{* *} \\
(2.595)\end{array}$ & $6.739 * *$ & 0.341 & 2.51 \\
\hline 13 & Gharibwal Cement Ltd. & -0.052 & $\begin{array}{l}.662^{* * *} \\
(3.346)\end{array}$ & $13.291^{* * *}$ & 0.439 & 2.65 \\
\hline 14 & Javedan Cement Ltd. & -0.069 & $\begin{array}{l}.820^{* * *} \\
(5.913)\end{array}$ & $34.958^{* * *}$ & 0.673 & 2.35 \\
\hline 15 & Kohat Cement Ltd. & 0.173 & $\begin{array}{l}.744^{* * *} \\
(3.854)\end{array}$ & $14.856^{* * *}$ & 0.553 & 2.27 \\
\hline 16 & Lucky Cement Ltd. & -0.049 & $\begin{array}{l}.748^{* * *} \\
(3.561)\end{array}$ & $12.682^{* * *}$ & 0.559 & 2.73 \\
\hline 17 & Mapple Leaf Cement Ltd. & -0.012 & $\begin{array}{l}.698 * * * \\
(3.376)\end{array}$ & $11.399 * * *$ & 0.487 & 2.43 \\
\hline 18 & Mustehkam Cement Ltd. & -0.074 & $\begin{array}{l}.679^{* * *} \\
(3.809)\end{array}$ & $14.512^{* * *}$ & 0.461 & 2.14 \\
\hline 19 & $\begin{array}{l}\text { Pakistan Slag Cement } \\
\text { Ltd. }\end{array}$ & 0.481 & $\begin{array}{l}.748^{* * *} \\
(3.904)\end{array}$ & $15.244^{* * *}$ & 0.560 & 2.26 \\
\hline 20 & Pioneer Cement Ltd. & -0.044 & $\begin{array}{l}.682^{* * *} \\
(3.090)\end{array}$ & $9.541^{* * *}$ & 0.456 & 2.33 \\
\hline 21 & Zeal Pak Cement Ltd. & -0.089 & $\begin{array}{l}.517^{* *} \\
(2.492)\end{array}$ & $6.211^{* *}$ & 0.268 & 2.61 \\
\hline
\end{tabular}

t-values are in parenthesis

***, and ${ }^{* * *}$ are significance levels at $1 \%, 5 \%$, and $10 \%$ respectively. 


\begin{tabular}{|c|c|c|c|c|c|c|}
\hline S. No. & Name of Company & Constant & $\boldsymbol{\beta}$ & F-Value & $\mathbf{R}^{2}$ & D-W \\
\hline 1 & Al-Abbas Cement Ltd. & -0.232 & $\begin{array}{c}.533^{* *} \\
(2.521)\end{array}$ & $6.357^{* *}$ & 0.284 & 2.68 \\
\hline 2 & Attock Cement Ltd. & -0.046 & $\begin{array}{c}0.459 \\
(0.731)\end{array}$ & 0.534 & 0.211 & 0.94 \\
\hline 3 & Bestway Cement Ltd. & -0.212 & $\begin{array}{l}.944^{* * *} \\
(4.046)\end{array}$ & $16.350^{* * *}$ & 0.891 & 3.16 \\
\hline 4 & Cherate Cement Ltd. & -0.039 & $\begin{array}{c}2.2 \\
(0.932)\end{array}$ & 0.869 & 0.049 & 2.70 \\
\hline 5 & Dadabhoy Cement Ltd. & 0.048 & $\begin{array}{l}.531^{* *} \\
(2.343)\end{array}$ & $5.491^{* *}$ & 0.282 & 1.96 \\
\hline 6 & Dadex Eternit Ltd. & 0.159 & $\begin{array}{l}.629^{* * *} \\
(3.338)\end{array}$ & $11.146^{* * *}$ & 0.396 & 2.16 \\
\hline 7 & Dandot Cement Ltd. & 2.034 & $\begin{array}{l}.835^{* * *} \\
(6.251)\end{array}$ & $39.081^{* * *}$ & 0.697 & 1.75 \\
\hline 8 & Deewan Cement Ltd. & 0.697 & $\begin{array}{l}.686^{* * *} \\
(3.982)\end{array}$ & $15.145^{* * *}$ & 0.471 & 2.04 \\
\hline 9 & $\begin{array}{l}\text { Deewan Hattar Cement } \\
\text { Ltd. }\end{array}$ & 0.0438 & $\begin{array}{c}-0.75 \\
(-1.605)\end{array}$ & 2.570 & 0.563 & 1.85 \\
\hline 10 & DG Khan Cement Ltd. & -0.254 & $\begin{array}{c}0.358 \\
(1.433)\end{array}$ & 2.054 & 0.128 & 2.35 \\
\hline 11 & Fauji Cement Ltd. & -0.206 & $\begin{array}{c}0.001 \\
(0.001)\end{array}$ & 0.001 & 0.001 & 2.68 \\
\hline 12 & Fecto Cement Ltd. & -0.1896 & $\begin{array}{c}0.311 \\
(1.178)\end{array}$ & 1.387 & 0.096 & 2.57 \\
\hline 13 & Gharibwal Cement Ltd. & -0.2178 & $\begin{array}{l}.591^{* * *} \\
(3.018)\end{array}$ & $9.106^{* * *}$ & 0.349 & 2.16 \\
\hline 14 & Javedan Cement Ltd. & -0.383 & $\begin{array}{l}.512^{* *} \\
(2.456)\end{array}$ & $6.033^{* *}$ & 0.262 & 2.27 \\
\hline 15 & Kohat Cement Ltd. & -0.074 & $\begin{array}{c}0.182 \\
(0.642)\end{array}$ & 0.412 & 0.03 & 2.93 \\
\hline 16 & Lucky Cement Ltd. & -0.203 & $\begin{array}{c}0.17 \\
(0.518)\end{array}$ & 0.269 & 0.029 & 2.75 \\
\hline 17 & Mapple Leaf Cement Ltd. & -0.686 & $\begin{array}{l}.770^{* * *} \\
(4.182)\end{array}$ & $17.491^{* * *}$ & 0.593 & 2.28 \\
\hline 18 & Mustehkam Cement Ltd. & -0.102 & $\begin{array}{c}0.321 \\
(1.396)\end{array}$ & 1.950 & 0.103 & 2.53 \\
\hline 19 & Pakistan Slag Cement Ltd. & -0.543 & $\begin{array}{l}.696^{* * *} \\
(3.35)\end{array}$ & $12.240^{* * *}$ & 0.484 & 2.16 \\
\hline 20 & Pioneer Cement Ltd. & -0.294 & $\begin{array}{l}0.3912 \\
(1.413)\end{array}$ & 1.998 & 0.354 & 2.00 \\
\hline 21 & Zeal Pak Cement Ltd. & -0.215 & $\begin{array}{c}0.332 \\
(1.453)\end{array}$ & 2.110 & 0.11 & 2.79 \\
\hline
\end{tabular}

$t$-values are in parenthesis

***, and ${ }^{* * *}$ are significance levels at $1 \%, 5 \%$, and $10 \%$ respectively. 


\begin{tabular}{|c|c|c|c|c|c|c|}
\hline S. No. & Name of Company & Constant & $\beta$ & F-Value & $\mathbf{R}^{2}$ & D-W \\
\hline 1 & Al-Abbas Cement Ltd. & -0.418 & $\begin{array}{l}.858^{* * *} \\
(6.670)\end{array}$ & $44.49^{* * *}$ & 0.736 & 1.72 \\
\hline 2 & Attock Cement Ltd. & 0.137 & $\begin{array}{c}0.553 \\
(0.938)\end{array}$ & 0.880 & 0.306 & 1.17 \\
\hline 3 & Bestway Cement Ltd. & 0.024 & $\begin{array}{c}0.506 \\
(0.830)\end{array}$ & 0.688 & 0.256 & 2.24 \\
\hline 4 & Cherate Cement Ltd. & -0.116 & $\begin{array}{c}0.331 \\
(1.448)\end{array}$ & 2.090 & 0.110 & 2.56 \\
\hline 5 & Dadabhoy Cement Ltd. & -0.009 & $\begin{array}{l}.533^{* *} \\
(2.360)\end{array}$ & $5.570^{* *}$ & 0.285 & 2.71 \\
\hline 6 & Dadex Eternit Ltd. & -0.007 & $\begin{array}{l}.441^{* *} \\
(2.028)\end{array}$ & $4.110^{* *}$ & 0.195 & 2.74 \\
\hline 7 & Dandot Cement Ltd. & 7.404 & $\begin{array}{l}.744^{* * *} \\
(4.580)\end{array}$ & $21.014^{* * *}$ & 0.553 & 1.95 \\
\hline 8 & Deewan Cement Ltd. & 1.183 & $\begin{array}{l}.680^{* * *} \\
(3.800)\end{array}$ & $14.59^{* * *}$ & 0.462 & 2.09 \\
\hline 9 & $\begin{array}{l}\text { Deewan Hattar Cement } \\
\text { Ltd. }\end{array}$ & 0.41 & $\begin{array}{c}-0.146 \\
(-0.208)\end{array}$ & 0.043 & 0.021 & 1.49 \\
\hline 10 & DG Khan Cement Ltd. & -0.654 & $\begin{array}{l}.599^{* *} \\
(2.801)\end{array}$ & $7.846^{* *}$ & 0.359 & 2.96 \\
\hline 11 & Fauji Cement Ltd. & -0.071 & $\begin{array}{c}0.034 \\
(0.097)\end{array}$ & 0.009 & 0.001 & 2.52 \\
\hline 12 & Fecto Cement Ltd. & 0.086 & $\begin{array}{c}-0.03 \\
(-0.107)\end{array}$ & 0.012 & 0.001 & 2.79 \\
\hline 13 & Gharibwal Cement Ltd. & 0.017 & $\begin{array}{l}-0.164 \\
(0.687)\end{array}$ & 0.473 & 0.027 & 3.33 \\
\hline 14 & Javedan Cement Ltd. & -0.35 & $\begin{array}{l}.567^{* * *} \\
(2.835)\end{array}$ & $8.035^{* *}$ & 0.321 & 2.39 \\
\hline 15 & Kohat Cement Ltd. & -0.091 & $\begin{array}{l}-.651^{* *} \\
(2.970)\end{array}$ & $8.820^{* *}$ & 0.424 & 2.39 \\
\hline 16 & Lucky Cement Ltd. & 0.111 & $\begin{array}{l}.692^{* *} \\
(2.872)\end{array}$ & $8.250^{* *}$ & 0.478 & 1.61 \\
\hline 17 & Mapple Leaf Cement Ltd. & -0.29 & $\begin{array}{l}.591^{* *} \\
(2.537)\end{array}$ & $6.437^{* *}$ & 0.349 & 2.47 \\
\hline 18 & Mustehkam Cement Ltd. & -0.226 & $\begin{array}{l}.482^{* *} \\
(2.267)\end{array}$ & $5.141^{* *}$ & 0.232 & 2.79 \\
\hline 19 & $\begin{array}{l}\text { Pakistan Slag Cement } \\
\text { Ltd. }\end{array}$ & 2.196 & $\begin{array}{l}.729^{* * *} \\
(3.685)\end{array}$ & $13.58^{* * *}$ & 0.531 & 2.24 \\
\hline 20 & Pioneer Cement Ltd. & -0.346 & $\begin{array}{c}.484^{*} \\
(1.836)\end{array}$ & $3.370^{*}$ & 0.235 & 1.97 \\
\hline 21 & Zeal Pak Cement Ltd. & 0.076 & $\begin{array}{l}-0.140 \\
(0.581)\end{array}$ & 0.338 & 0.019 & 2.99 \\
\hline
\end{tabular}

$t$-values are in parenthesis

***, and ${ }^{* * *}$ are significance levels at $1 \%, 5 \%$, and $10 \%$ respectively. 
Table 7: Ranking of the Companies

\begin{tabular}{|c|c|c|c|c|}
\hline S. No. & Name of Company & $\begin{array}{c}\text { Utilization } \\
\text { Index }\end{array}$ & $\begin{array}{c}\text { Performance } \\
\text { Index }\end{array}$ & $\begin{array}{c}\text { Efficiency } \\
\text { Index }\end{array}$ \\
\hline 1 & Al-Abbas Cement Ltd. & 16 & 8 & 1 \\
\hline 2 & Attock Cement Ltd. & 2 & 12 & 13 \\
\hline 3 & Bestway Cement Ltd. & 3 & 1 & 14 \\
\hline 4 & Cherate Cement Ltd. & 15 & 11 & 15 \\
\hline 5 & Dadabhoy Cement Ltd. & 5 & 9 & 9 \\
\hline 6 & Dadex Eternit Ltd. & 18 & 6 & 12 \\
\hline 7 & Dandot Cement Ltd. & 7 & 2 & 2 \\
\hline 8 & Deewan Cement Ltd. & 21 & 5 & 5 \\
\hline 9 & Deewan Hattar Cement Ltd. & 1 & 21 & 19 \\
\hline 10 & DG Khan Cement Ltd. & 19 & 14 & 6 \\
\hline 11 & Fauji Cement Ltd. & 4 & 20 & 16 \\
\hline 12 & Fecto Cement Ltd. & 17 & 17 & 17 \\
\hline 13 & Gharibwal Cement Ltd. & 14 & 7 & 20 \\
\hline 14 & Javedan Cement Ltd. & 6 & 10 & 8 \\
\hline 15 & Kohat Cement Ltd. & 10 & 18 & 21 \\
\hline 16 & Lucky Cement Ltd. & 8 & 19 & 4 \\
\hline 17 & Mapple Leaf Cement Ltd. & 11 & 3 & 7 \\
\hline 18 & Mustehkam Cement Ltd. & 13 & 16 & 11 \\
\hline 19 & Pakistan Slag Cement Ltd. & 9 & 4 & 3 \\
\hline 20 & Pioneer Cement Ltd. & 12 & 13 & 10 \\
\hline 21 & Zeal Pak Cement Ltd. & 20 & 15 & 18 \\
\hline
\end{tabular}

\section{Conclusion}

Working capital management is highly important for firms since it plays a vital role to generate further returns for the stakeholders; however, it has attracted less attention of researchers and practitioners. When working capital is managed improperly i.e., allocating more than the optimal level of resources to current assets will result in in-efficient utilization and resulting in reduced benefits of short term investments. On the other hand, if the level of working capital is too low, the company may miss a lot of profitable investment opportunities or suffer short term liquidity crisis, leading to degradation of company credit standing, as it cannot effectively meet the temporary capital requirements. It is therefore may be believed that various external and internal factors that may induce the firms to strike a balance between meeting unforeseen capital requirements and avoiding non-efficient management of capital. The current study uses some of those external and internal factors to explore the determinants of working capital requirements of a firm.

The present study is an attempt to investigate the efficiency of the cement companies in Pakistan for management of working capital during 1988 to 2009. Instead of using the common method of analyzing different working capital management ratios, three index values representing the average performance of the components of current assets, the degree of utilization of the total current assets in relation to sales and the efficiency in managing the working capital have been computed for the sample firms for the window period. Using industry norm as target efficiency level of the individual firms, an evaluation has 
been made with regards to the speed of achieving that target level of efficiency by an individual firm during the study period.

Empirical results revealed that the cement firms of Pakistan did perform remarkably well during this period. Industry average for efficiency index was greater than one in 18 out of 20 years of the study period. However, the existence of a very high degree of inconsistency in this matter clearly points out the need for adopting sound working capital management policies by these firms. In terms of achieving the target level (industry norm) of efficiency by the firms, Al-Abbas Cement and Dandot Cement were the most successful firms followed by Pakistan Slag and Lucky Cement. In view of the observed o values, once again it may not be unwise to conclude that firms under study should take necessary steps in order to improve efficiency. Further, as evident from the results, the cement sector is performing well operationally, then the questions arises, what happened to the profitability of these firms? This important question is left for future research to investigate the determinants of profitability in cement sector of Pakistan. This also provides an important implication for stakeholders of cement industry to look into this issue very carefully and rigorously. This is particularly important in the context of the present competitive situation of the market. Present study also suggests that a further investigation may be helpful for identifying the forces that govern this chronic nature of inefficiency present in the Pakistani cement companies in terms of working capital management.

\section{References}

Afza, T. \& Nazir, S. M. (2007a). Working Capital Management Policies of Firms: Empirical Evidence from Pakistan. In the Proceedings of 9th South Asian Management Forum (SAMF) on February 24-25, North South University, Dhaka, Bangladesh.

Afza, T. \& Nazir, S. M. (2007b). Is it better to be Aggressive or Conservative in Managing Working Capital? Journal of Quality and Technology Management, 3(2): 11-21.

Afza, T. \& Nazir, S. M. (2008). Working Capital Approaches and Firm's Returns in Pakistan. Pakistan Journal of Commerce and Social Sciences, 1(1): 25-36.

Baig, M. R. (2008). Cement Industry. Economic Pakistan (February 12, 2008).

Bhattacharya, H. (1997). Total Management by Ratios, Sage Publication India Pvt. Ltd. New Dehli.

Brigham, E. F. and Ehrhardt, M. C. (2004). Financial Management: Theory and Practice (11 ${ }^{\text {th }}$ Edition). New York: South-Western College Publishers.

Carpenter, M. D. and Johnson, K. H. (1983). The Association between Working Capital Policy and Operating Risk. The Financial Review, 18(3): 106-106.

Deloof, M. (2003). Does Working Capital Management Affect Profitability of Belgian Firms? Journal of Business, Finance and Accounting, 30(3\&4): 573-587.

Eljelly, A. M. A. (2004). Liquidity-Profitability Tradeoff: An Empirical Investigation in an Emerging Market. International Journal of Commerce and Management, 14(2): 48-61.

Filbeck, G. and Krueger, T. (2005). Industry Related Differences in Working Capital Management. MidAmerican Journal of Business, 20(2): 11-18.

Gardner, M. J., Mills, D. L. and Pope, R. A. (1986). Working Capital Policy and Operating Risk: An Empirical Analysis. The Financial Review, 21(3): 31-31.

Ghosh, S. K. and Maji, S. G. (2004). Working Capital Management Efficiency: A Study on the Indian Cement Industry. The Management Accountant, 39(5): 363-372.

Gitman, L. J. (2005). Principles of Managerial Finance (11 th Edition). New York: Addison Wesley Publishers.

Gombola, M. J. and Ketz, J. E. (1983). Financial Ratio Patterns in Retail and Manufacturing Organizations. Financial Management, 12 (2): 45-56.

Gupta, M. C. (1969). The Effect of Size, Growth and Industry on the Financial Structure of Manufacturing Companies. Journal of Finance, 24(3): 517-529.

Gupta, M. C. and Huefner, R. J. (1972). A Cluster Analysis Study of Financial Ratios and Industry Characteristics. Journal of Accounting Research, 10(1): 77-95.

Hall, C. (2002). Total Working Capital Management. AFP Exchange, 22(6): 26-32.

Harris, A. (2005). Working Capital Management: Difficult, but Rewarding. Financial Executive, 21(4): 5253.

Howorth, C. and Westhead, P. (2003). The Focus of Working Capital Management in UK Small Firms. Management Accounting Research, 14(2): 94-111.

Johnson, C. G. (1970). Ratio Analysis and the Prediction of Firm Failure: Comment. Journal of Finance, 25(5): 1166-1168. 
Jose, M. L., Lancaster, C. and Stevens, J. L. (1996). Corporate Returns and Cash Conversion Cycle. Journal of Economics and Finance, 20(1): 33-46.

Lamberson, M. (1995). Changes in Working Capital of Small Firms in Relation to Changes in Economic Activity. Mid-American Journal of Business, 10(2): 45-50.

Lazaridis, I. and Tryfonidis, D. (2006). Relationship between Working Capital Management and Profitability of Listed Companies in the Athens Stock Exchange. Journal of Financial Management and Analysis, 19 (1): 26-35.

Long, M. S., Malitz, I. B. and Ravid, S. A. (1993). Trade Credit, Quality Guarantees, and Product Marketability. Financial Management, 22: 117-127.

Maxwell, C. E., Gitman, L. J. and Smith, S. (1998). Working Capital Management and Financial-Service Consumption Preferences of US and Foreign Firms: A Comparison of 1979 and 1996 Preferences. Financial Practice and Education, 8(2): 46-52.

Moyer, R. C., McGuigan, J. R. and Kretlow, W. J. (2005). Contemporary Financial Management (10 ${ }^{\text {th }}$ Edition). New York: South-Western College Publication.

Nazir, M. S. and Afza, T. (2009a). Working Capital Requirements and the Determining Factors in Pakistan. ICFAI Journal of Applied Finance, 15(4): 28-38.

Nazir, M. S. and Afza, T. (2009b). A Panel Data Analysis of Working Capital Management Policies. IBA Business Review, 4(1): 143-157.

Prasad, R. S. (2001). Working Capital Management in Paper Industry. Finance India, 15(1): 185-188.

Pinches, G. E. (1991). Essentials of Financial Management (4 ${ }^{\text {th }}$ Edition). New York: HarperCollins College Division.

Pinches, G. E., Mingo, K. A. and Caruthers, J. K. (1973). The Stability of Financial Patterns in Industrial Organizations. Journal of Finance, 28(2): 389-396.

Rehman, A. (2006). Working Capital Management and Profitability: Case of Pakistani Firms (Unpublished Dissertation). Pakistan: COMSATS Institute of Information Technology Islamabad.

Rehman, A. and Nasr, V. (2007). Working Capital Management and Profitability: Case of Pakistani Firms. International Review of Business Research, 3 (2): 275-296.

Rehman. A, Qayyum, A. Afza, T and Bodla, M. A. (2010). Sector-wise Analysis of Working Capital Management and Firm Performance in Manufacturing Sector of Pakistan. Interdisciplinary Journal of Contemporary Research in Business, 2(7): 412-437.

Shin, H. H. and Soenen, L. (1998). Efficiency of Working Capital and Corporate Profitability. Financial Practice and Education, 8: 37-45.

Smith, K. (1980). Profitability versus Liquidity Tradeoffs in Working Capital Management, in Readings on the Management of Working Capital. New York: St. Paul, West Publishing Company.

Smith, M. B. and Begemann, E. (1997). Measuring Association between Working Capital and Return on Investment. South Africa Journal of Business Management, 28(1): 1-5

Soenen, L. A. (1993). Cash conversion cycle \& corporate profitability. Journal of Cash Management, 13(4): 53-58

State Bank of Pakistan (SBP). Balance Sheet Analysis of Joint Stock Companies of Karachi Stock Exchange, various reports. SBP, Karachi: Pakistan.

Teruel, P. J. G. and Solan, P. M. (2005). Effects of Working Capital Management on SME Profitability. Working Papers Series. Dept. Organización de Empresas y Finanzas, Facultad de Economía y Empresa, Universidad de Murcia, Campus Espinardo, Spain.

Van-Horne J. C. and Wachowicz, J. M. (2004). Fundamentals of Financial Management (12 ${ }^{\text {th }}$ Edition). New York: Prentice Hall Publishers.

Weinraub, H. J. and Visscher, S. (1998). Industry Practice Relating To Aggressive Conservative Working Capital Policies. Journal of Financial and Strategic Decision, 11(2): 11-18.

Yadav, R. A. (1986). Working Capital Management: A Parametric Approach. The Chartered Accountant, 952. 